\title{
Integrated Cost Allocation of Transmission Usage under Electricity Markets
}

\author{
Hermagasantos Zein ${ }^{1}$, Ignatius Riyadi Mardiyanto ${ }^{2}$, and Ali Mashar ${ }^{3}$
}

\begin{abstract}
Cost allocation of transmission usage on the power networks is an important issue especially in the modern electricity market mechanism. In this context, all costs that have been embedded in the transmission, embedded cost, should be covered by the transmission users. This paper follows general methods, where generators are fully responsible to cover the embedded cost. It proposes a method to determine the cost allocation of transmission usage based on decomposition through the superposition techinique to determine power flow contributions from an integrated base case of the results of the power flow calculations of all transactions, bilateral and nonbilateral contracts. Mathematically, the applied formulations are illustrated clearly in this paper. The proposed method has been tested with 5-bus system and the results are much different compared to a few of the published methods. This is shown by the test results on the 5 bus system. The published methods produce total power flow contributions in each line is greater than the actual. And they earn total revenues approximately 11.6\% greater than the embedded cost. While on the proposed method, the power flow contributions are equal to the actual and the revenues are equal to the embedded cost. It shows also that the proposed method gives results as expected.
\end{abstract}

Keywords-Transmission, cost allocation, proposed method, published method, superposition technique

\begin{abstract}
Abstrak-Alokasi Biaya penggunaan transmisi pada jaringan listrik merupakan masalah penting terutama dalam mekanisme pasar tenaga listrik modern. Dalam konteks ini, semua biaya yang telah tertanam dalam transmisi (embedded costs) harus ditanggung oleh pengguna-pengguna transmisi. Tulisan ini mengikuti metode umum, di mana generator-generator bertanggung jawab penuh untuk menutupi embedded costs tersebut. Tulisan ini mengusulkan sebuah metode untuk menentukan alokasi biaya penggunaan transmisi berdasarkan dekomposisi melalui teknik superposisi untuk menentukan kontribusi-kontribusi aliran daya dari suatu integrated base case hasil perhitungan aliran daya dari semua transaksi, kontrakkontrak bilateral dan nonbilateral. Secara matematis, formulasi-formulasi yang diterapkan telah diilustrasikan dengan jelas dalam tulisan ini. Metoda yang diajukan tersebut telah diuji dengan sistem 5-bus dan hasilnya sangat berbeda dibandingkan dengan beberapa metode yang telah publikasikan tersebut. Ini ditunjukan oleh hasil-hasil tes pada sistem 5 bus. Metode-metode yang telah dipublikasikan tersebut menghasilkan kontribusi aliran daya total di setiap line lebih besar dari aktualnya. Dan metode-metode ini memperoleh total pendapatan sekitar 11,6\% lebih besar dari pada embedded costs. Sedangkan pada metode yang diusulkan, kontribusi aliran daya tersebut sama dengan aktualnya dan pendapatan sama dengan embedded costs. Ini menunjukkan juga bahwa metode yang diusulkan memberikan hasil seperti yang diharapkan.
\end{abstract}

Kata kunci-Transmisi, alokasi biaya, terpadu, dekomposisi, teknik superposisi

\section{INTRODUCTION}

ost allocation of the transmission usage is an

important issue on electricity industry in the context of open access transmission. Transmission is always maintained under natural monopoly company. However, transmission provider is required for offering the basic transmission services in conjunction with a number of mandatory, and/or voluntary ancillary services. Experimentally, these cases have been studied by A. Zobian and M.D. Ilic, [1], and L. Willis et. al., [2]. Basic transmission service refers to the path provision as function of the transmission grid while ancillary services, such as: operating reserves, regulation, load following and voltage control, are necessary for maintaining the reliability of the bulk-system as well as undertaking commercial transactions across the grid.

A few references have published various methods to calculate cost allocation of transmission usage, such as Generation Shift Distribution Factors (GSDFs), Line Utilization Factors (LUFs), Bialek and Kirschen tracing algorithms. The methods of publication have been

Hermagasantos Zein is with Department of Energy Conversion, POLBAN,Bandung, 6468, Indonesia. E-mail: hermaga_s@yahoo.co.id. Ignatius Riyadi Mardiyanto is with Department of Energy Conversion, POLBAN, Bandung, 6468, Indonesia. E-mail:Ig_R_M@yahoo.com. Ali Mashar is with Department of Energy Conversion, POLBAN, Bandung, 6468, Indonesia. E-mail: amashar69@yahoo.com. reviewed by [3] through numerical examples of the 5-bus test system from [1] and their results are different enough among them, see Tables 2, 3, 4 and 5. Tables 2 and 3 show the results of bilateral contracts that are calculated separatedly from the base case (results of load flow without the bilateral contracts). Whereas Tables 4 and 5 are results from the generators 1 and 2 which are based on the base case only. In the methods that have been published, the methodology implemented to calculate the transmission usage cost uses unintegrated base case, i.e. seperated between generators and bilateral contracts. This causes EC (embedded cost of transmission) less than the revenues (from generators and bilateral contracts). It can be concluded that by using these methods, the transmission provider has profits. The profit can make the transmission provider to be involved in business so that it can not act fairly to all entities (bilateral contracts and non bilateral contracts).

This paper proposes the integrated calculation to determine cost allocation of transmission usage through decomposition technique. Initial step begins from the results of load flow for all entities, or integrated results, as a base case. The next step, the base case will be used to determine power flow contributions in each line from generators by using decomposition technique [4]. In this case, the working equation of network is manipulated so that superposition techniques can be applied. Automatically, it produces power flow contributions in 
each line from every generator of entity. Finally, process is continued to calculate cost allocation base on general equation from MW-Mile regulation.

There are two differences between the proposed method and the publication methods above, namely: the base case used in accordance to the facts or bilateral contracts that are not separated. In addition, the formulations are applied without any approach or assumption. These are expected to ensure fairness in determining the cost allocation of transmission usage. The proposed method will be explained more detail in Section II.

In this case,the transmission provider can not take a profit, since the embedded costs are equal to the revenues of generators. The transmission provider should act fairly to all generators since they are responsible for covering the embedded costs. In this paper, the proposed method is tested with the 5-bus system. The results of the test will then be compared to the results of the published methods. The test is aimed to see performance of the proposed method whether it can be applied.

\section{METHOD}

\section{A. Formulations of Cost}

The usage of transmission facilities is measured by absolute flow values, and the transmission facility costs are allocated in proportion to the ratio of flow magnitude contributed by a particular transaction and the sum of absolute flows caused by all transmission users. The following equation may give more general expression of MW-Mile rule.

$$
T C_{i}=\sum_{k \in K} C_{k} \frac{\left|F_{i, k}\right|}{\sum_{t \in T}\left|F_{t, k}\right|}
$$

Where $\mathrm{TC}_{\mathrm{i}}$ is total cost allocated to generator $\mathrm{i}, C_{k}$ is embedded costs of facility $\mathrm{k},\left|F_{t, k}\right|$ is magnitude of flow on facility $\mathrm{k}$ caused by generator $\mathrm{t}, \mathrm{K}$ and $\mathrm{T}$ represent the sets of transmission facilities and generators on the system, respectively. This equation shows that the direction of flow does not influence responsibility payment to the transmission provider. This analogs to TOL (Tax of Line) usage for vehicles. Power magnitude used in the equation consists of either active power (MW) or apparent power (MVA) as the base calculation and generally MW is chosen.

This paper uses also the equation to calculate the cost allocation of transmission usage, and it chooses MW as the base calculation.

\section{B. Decomposition Methods}

Every bus (node) is presented by one generator and one load as shown in Figure 1.

From Figure 1, the currents can be expressed by theis following equation.

$$
I_{i}=I_{i}^{G}-I_{i}^{D}
$$

Where: $I_{i}$ is injection current at bus $\mathrm{i}, I_{i}^{G}$ is current generated by generator at bus $\mathrm{i}$ and $I_{i}{ }^{D}$ is current absorbed by the load at bus i. Whereas power can expressed by theis following equation.

$$
\begin{aligned}
S_{i} & =S_{i}^{G}-S_{i}^{D} \\
& =\left(P_{i}^{G}-P_{i}^{D}\right)+j\left(Q_{i}^{G}-Q_{i}^{D}\right)
\end{aligned}
$$

Where: $S_{i}$ is injection MVA at bus $\mathrm{i}, S_{i}^{G}$ is MVA generated by generator at bus i, $S_{i}^{D}$ is MVA absorbed by load at bus i, $P_{i}^{G}$ and $P_{i}{ }^{D}$ are MWs generated by generator and absorbed by the load at bus i, respectively. $Q_{i}{ }^{G}$ and $Q_{i}{ }^{D}$ are reactive powers generated by generator and absorbed by the load at bus $i$, respectively. The current flows into the load:

$$
\begin{aligned}
I_{i}^{D} & =\left(\frac{S_{i}^{D}}{V_{i}}\right)^{*} \\
& =y_{i}^{D} V_{i}
\end{aligned}
$$

where,

$$
\begin{aligned}
y_{i}^{D} & =\frac{\left(S_{i}^{D}\right)^{*}}{\left|V_{i}\right|^{2}} \\
& =\frac{P_{i}^{D}-j Q_{i}^{D}}{\left|V_{i}\right|^{2}}
\end{aligned}
$$

General working equation of the electric grid system in matrix is,

$\left[I_{\text {bus }}\right]=\left[Y_{\text {bus }}\right]\left[V_{\text {bus }}\right]$

where $\left[I_{b u s}\right]$ is bus injection current matrix, $\left[Y_{b u s}\right]$ is bus admittance matrix and $\left[V_{b u s}\right]$ is bus voltage matrix. Whereas the bus injection current matrix consists of bus injection current matrix of generator, $\left[I^{G}\right.$ bus $]$, and bus injection current matrix of demand, $\left[I^{D}\right.$ bus $]$. So, Equation 6 can be rewrited as:

$\left[I_{\text {bus }}^{G}\right]-\left[I_{\text {bus }}^{D}\right]=\left[Y_{\text {bus }}\right]\left[V_{\text {bus }}\right]$

or,

$\left[I_{\text {bus }}^{G}\right]=\left[Y_{\text {bus }}\right]\left[V_{\text {bus }}\right]+[\mathrm{I}]\left[\left[I_{\text {bus }}^{D}\right]\right.$

Where $[I]$ is identity matrix. Based on [4], the current flows to the demand at bus $\mathrm{i}$ in matrix form of Equation 8 is substituted into Equation 10 and yield.

$\left[I_{\text {bus }}^{G}\right]=\left[Y_{\text {bus }} \rrbracket V_{\text {bus }}\right]+\left[\mathrm{y}_{\text {bus }}^{D}\right]\left[V_{\text {bus }}\right]$

or

$\left.\left[I_{\text {bus }}^{G}\right]=\left[Y_{\text {bus }}^{\#}\right] V_{\text {bus }}\right]$

Where $\left[\mathrm{y}_{\text {bus }}^{D}\right]$ is diagonal matrix of load admittances expressed by Equation 9 and,

$\left[Y_{b u s}^{\#}\right]=\left[Y_{b u s}\right]+\left[y_{b u s}^{D}\right]$

where $\left[Y_{b u s}^{\#}\right]$ is a new bus admittance matrix. From the Equation 10 is get bus voltage, that is

$\left[V_{\text {bus }}^{G}\right]=\left[\mathrm{Z}_{\text {bus }}^{\#}\left[I_{\text {bus }}^{G}\right]\right.$

where,

$\left[Z_{\text {bus }}^{\#}\right]=\left[Y_{\text {bus }}^{\#}\right]^{-1}$

where $\left[Z_{\text {bus }}^{\#}\right]$ is a new bus impedance matrix.

Power contribution of generator that flows in every line can then be calculated by using superposition technique. For example, for generator at bus i, Equation 12 can be transformed into:

$\left[\begin{array}{l}V_{1}^{G i} \\ V_{2}^{G i} \\ \bullet \\ \bullet \\ \bullet \\ V_{n}^{G i}\end{array}\right]=\left[\begin{array}{cccccc}Z_{11}^{\#} & Z_{12}^{\#} & \bullet & \bullet & \bullet & Z_{1 n}^{\#} \\ Z_{21}^{\#} & Z_{21}^{\#} & \bullet & \bullet & \bullet & Z_{2 n}^{\#} \\ \bullet & \bullet & \bullet & \bullet & \bullet & 0 \\ \bullet & \bullet & \bullet & \bullet & \bullet & 0 \\ \bullet & \bullet & \bullet & \bullet & \bullet & 0 \\ Z_{n 1}^{\#} & Z_{n 2}^{\#} & \bullet & \bullet & \bullet & Z_{n n}^{\#}\end{array}\right]\left[\begin{array}{l}0 \\ 0 \\ 0 \\ I_{i}^{G} \\ 0 \\ 0\end{array}\right]$ 
Where $V_{j}^{G i}$ is the voltage at bus $\mathrm{j}$ that is caused by generator in bus i. $Z_{j i}^{\#}$ is element of new bus impedance matrix at row j with column i and $I_{i}^{G}$ is current generated by generator at bus $i$ that is got from the base case. From equation 14 , the voltage generated in each bus is:

$V_{j}^{G i}=Z_{j i}^{\#} I_{i}^{G}$

Figure 2 will be used to calculate current flow for transmission line. This figure is phi equivalent circuit of a line having admittance $y_{j k}$ and half line charging susceptance $y_{j k}^{s h}$. The line is connected from bus $\mathrm{j}$ to bus $\mathrm{k}$, where $V_{j}^{G i}$ and $v_{j}^{G i}$ are nodal voltage of the line as consequence of power injection from bus i. From that figure, the current generated by the generator at bus $i$ flows in line $\mathrm{j}-\mathrm{k}$ and it can be easily determined through circuit theory, that is,

$I_{j k}^{G i}=\left(V_{j}^{G i}-V_{k}^{G i}\right) y_{j k}+V_{j}^{G i} y_{j k}^{s h}$

or

$I_{j k}^{G i}=F_{j k}^{G i} I_{i}^{G i}$

Where $V_{j k}^{G i}$ is the current generated by generator at bus $i$ that flows in line $\mathrm{j}-\mathrm{k}, F_{j k}{ }^{G i}$ is a multiplier-factor for generator $\mathrm{i}$ and,

$F_{j k}^{G i}=\left(Z_{j i}^{\#}-Z_{k i}^{\#}\right) y_{j k}+Z_{j i}^{\#} y_{j k}^{s h}$

Finally, power contribution of the generator $i$ on the line j-k can be easily separated after current contribution of generator $\mathrm{i}$ on the line $\mathrm{j}-\mathrm{k}$ is known, that is

$$
\begin{aligned}
S_{j k}^{G i} & =V_{j}\left(I_{j k}^{G i}\right)^{*} \\
& =V_{j}\left(F_{j k}^{G i}\right)^{*}\left(I_{j k}^{G i}\right)^{*} \\
& =P_{j k}^{G i}+j Q_{j k}^{G i}
\end{aligned}
$$

Where $S_{j k}{ }^{G i}$ is MVA of generator $i$ that flows in the line $\mathrm{j}$ $\mathrm{k}, V_{j}$ is voltage at bus $\mathrm{j}$ that was got from the base case, $\left(I_{j k}{ }^{G l}\right)^{*}$ and $\left(F_{j k}{ }^{G i}\right)^{*}$ are conjugates of $\left(I_{j k}{ }^{G i}\right)$ and $\left(F_{j k}{ }^{G i}\right)$ respectively, and $P_{j k}{ }^{G i}$ and $Q_{j k}{ }^{G i}$ are active and reactive powers from generator $\mathrm{i}$ that flow in the line $\mathrm{j}-\mathrm{k}$.

\section{Algorithm}

The proposed method explained in section II needs clearer procedure, so that it can be applied in computer calculations. These procedures are steps of algorithm to run a program from the proposed method. Then the procedure in this paper are realized by an algorithm as the following steps:

Step-0 : Start.

Step-1 : Input data.

Step-2 : Run load flow for step-1condition.

Step-3 : Form new admittance matrix, Equation 9.

Step-4 : Form $\left[Z_{\text {bus }}^{\#}\right]$.

Step-5 : Determine an observated entity and calculate voltage every bus.

Step-6 : Calculate currents that flow to every line base on step-5.

Step-7 : Determine power contribution in every line.

Step-8 : Continue to step-5 for another entity until all entities have been processed.

Step-9 : Calculate cost allocation of transmission usage for every entity.

Step-10: Write Results.

Step-11: Finish.

Step-1 inputs all data, both data of embedded costs of every line and parameters of system. The data are used to obtain integrated base case by running load flow program in step-2. The integrated base case is used to calculate bus admittance through Equation 5 and then forming bus adminttance matrix through Equation 11 in step-3. Afterward, it is forming a bus impedance matrix from the bus admittance matrix in step-4. Choose a generator to be observated then uses Equation 14 to determine bus voltages in step-5. After obtaining bus voltages, it is continued to calculate current flows in every line from the generator through Equation 16 or 17 in step-6. By using Equation 19, power flows in every line from the generator can already be calculated in step7. In step-8 the process goes back to step-5 and choose again one of the other generators until all generators have been processed. Next step, it is continued to calculate cost allocation for every generator in the step10. Finally, it is obtained cost allocations of transmission usage from each generator and process is stopped.

\section{RESULTS AND DISCUSSION}

\section{A. Numerical Examples}

This section presents an illustrative example based on a 5-bus test system proposed by [3]. It is required to see performance of the proposed method discussed above. The 5-bus test system depicted in Fig. 3 and table 1 gives the transmission data including the base case flows and the transmission revenue requirements. In this case, the loads at bus 3, 4 and 5 are (45+j15 MVA), (40+j5 MVA) and $(60+\mathrm{j} 10 \mathrm{MVA})$, respectively. The generator from bus 2 is fixed at $20 \mathrm{MW}$ and bus 1 is the slack bus.

\section{B. Published Methods}

Tables 2, 3, 4 and 5 below are copied from [3]. These tables show the results of the methods of publication above. Tables 2 and 3 are for generators, whereas tables 4 and 5 are for bilateral contract transaction. Where the transmission usages and charges for generator on the tables 2 and 3 are determined through the base case without bilateral contract transactions. Transactionrelated flows and charges for bilateral contract transaction on the tables 4 and 5 are determined through wheeling transaction. They show that the generatorrelated MW flows and transmission charges determined using GGDFs and LUFs are very close. It means that there is no significant difference in using DC or AC sensitivity as far as the MW flow is concerned. In general, the Bialek tracing algorithm gives similar results as those by sensitivity based methods and therefore they may be used equivalently for the same purposes. Both tracing algorithms (Bialek and Kirchen) give zero charging for G2, and full responsibility of G1 to lines 12 and $1-3$. Where $\mathrm{T} 1$ is the fisrt bilateral contract (for 5 MW) between bus 1 as generations and bus 5 as loads, and $\mathrm{T} 2$ is the second bilateral contract (for $5 \mathrm{MW}$ ) between bus 4 as generations and bus 2 as loads.

From Tables 4 and 5 show the transaction-related flows determined by Generation Shift Distribution Factors (GSDFs), Line Utilization Factors (LUFs) and Power Flow Decomposition (PFD) algorithms. In the tables, the original MW-Mile cost allocation rule is used to distribute the revenue requirements to each transaction including the one representing the base case generations and loads. The bilateral contract charges calculated by the PFD algorithms using two distinguished variables: 
MW-Mile and MVA. The tables can be noticed that the transaction-related MW flows and the wheeling charges determined by different methods are very close when the transmission capacity use is measured by MW flows. In particular, the results from GSDFs and PFD algorithms are almost identical since both algorithms assume that the bus voltage is close to 1.0 p.u. This finding is in general true for the evaluation of wheeling transactions because usually the amount of transacted power is relatively small compared to the native flows on the system. On the other hand, the costs allocated to both transactions would be reduced when the transmission capacity use is measured by MVA flows. In this simple example, the assumed wheeling transactions only involve real power and thus their contributions to the network reactive flows are insignificant with reference to the base case flows.

However, when studied further, it shows that the revenues of the generators as nonbilateral contract and bilateral contract will always be greater than the total embedded costs. It would be even greater if the forces of bilateral contracts greater. This condition is not compatible with the desired spirit in this paper, that there is no advantage for transmission providers.

\section{Proposed Method}

Evaluation of transmission usage in the proposed method is done integratedly. The base case is determined based on power flow calculation results where the nonbilateral contracts (generators) and the bilateral contracts operate simultaneously, or called integrated. Therefore, bilateral constract transactions (T1 and T2) are added into the Figure 3 so that it yields Figure 4 (it is said integrated system).

Table 6 and 7 are load flow results from Figure 4 and they are used as base case in this paper. Table 6 consists of voltage in pu and powers of generator and loads. At bus 1 consists of $\mathrm{G} 1=130.37 \mathrm{MW}$ and GT1=5 MW. Power capacity of bilateral contract transactions is very small so that their reactive powers can be ignored. From the Table 6, the composition from generators (G1+G2) and bilateral contract transactions (T1+T2) are 150.0259 MW and 10 MW (or $93.8 \%$ and $6.2 \%$ ), respectively. Whereas table 7 consists of power flows in every line base on the Table 6 .

Table 8 is the calculation results of the proposed method for the case on Figure 4. It contains MW contribution to every line from all generators (G1, G2, GT1\&GT2) and the last row contains the cost allocation of transmission usage of the all transactions.

\section{Discussion}

On the methods of publication, the base case is separated from bilateral contract transactions. Tables 2 and 3 are transmission usages and charges for G1 and G2, respectively. Whereas Tables 4 and 5 are transaction-related flows and charges for the bilateral contract transactions (T1 and T2), respectively. For T1 and $\mathrm{T} 2$, thier calculations are determined separatedly so that every power generated by them will always be absorbed by the grid. Here, the bilteral contract transactions are assumed as wheeling transactions. Every power generated by wheeling transaction will flow toward its load. From Tables 4 and 5 show cost allocation between $\mathrm{T} 1$ in table 4 and T2 in Table 5 is very close, i.e. about 4.5 \$/MW.

Revenues of G1 and G2 have covered the total EC of transmission, whereas revenues of $\mathrm{T} 1$ and $\mathrm{T} 2$ are a benefit for transmission provider. This is not suitable with asumption that expresses transmission provider as non-profit board. One case again, it is not fair for the generators since they have to take responsibility for covering EC. Whereas bilateral contract transactions also use transmission to deliver their powers and it can lead bottle necks in the grid. If bottle necks occur, some generators have to reduce their power and the others have to increase it's power in order to secure the system. This causes all results of earlier calculations have to be adjusted again.

On the proposed method, the base case is resulted of load flow calculations that was integrated. The base case is shown in the Tables 6 and 7. From Table 6, bus 1 as swing bus, generates $135.5137 \mathrm{MW}$ that consists of the powers from G1 $=130.51370 \mathrm{MW}$ and GT1 $=5 \mathrm{MW}$. The bus has not load, so both power from G1 and GT1 are delivered to the grid. G2 at bus 2 generates $20 \mathrm{MW}$ and one part of its power was absorbed by load of T2. GT2 at bus 4 generates $5 \mathrm{MW}$ and the most power is absorbed by the load at that bus. Table 7 shows MVAR flows that are very small of MW flows. Therefore, the MVAR flows are not used in determining cost allocation of transmission usage.

Table 9 is the cost allocation results of the prososed method and the methods of publication. The cost allocation of the method comes from Table 8 and the methods of publication comes from Tables 2, 3, 4 and 5 . Row 5 is combination of Bialek and PFD-MW methods where the cost allocation for generators are calculated by Bialek method and the bilateral contract transactions are calculated by PFD method. Row 6 is combination of Kirchen and PFD-MVA methods, where the cost allocation for generators are calculated by Kirchen method and the bilateral contract transactions are calculated by PFD method.

Table 9 shows cost allocation for G2 which are less than G1 for all methods. This is caused by MW contribution at line 4-5 is very small, $0.0815 \mathrm{MW}$, for $\mathrm{G} 2$, whereas the ECof the line is biggest, i.e. $0.8250 \mathrm{x}$ $10^{6} \$$. This case contradicts to T2 that distributes its enough big power at the line 4-5, so that its cost allocation $(3,461496 \$ / \mathrm{MW})$ is greater than the cost allocation of T1 (2,4079 \$/MW). The proposed method produces cost allocation for belateral contract transactions about $3.5 \$ / \mathrm{MW}$, whereas the proposed methods produce cost allocation about $4.5 \$ / \mathrm{MW}$. It is caused by separation between generators and bilateral contract transactions in determining cost allocation for the methods of publication. The cost allocation (for bilateral contract transactions) refers to the base case in the Table 1 produces higher cost allocation. This is caused by sum of magnitude power flows greater or equal to the sum of power flows for every line and it is expressed by Equation 20.

$$
\sum \mid \text { Power flow } \mid \geq \sum \text { Power flow }
$$

From table 1 the Total Embedded Cost (TEC) for the 5 bus system in the fig. 3 , is obtained, i.e. $3.3148\left(10^{6}\right.$ $\$ /$ year) or 378.4018 \$/hour. All entities (both generators and bilateral contract transactions) have to cover that TEC. In the paper, the cost allocations are based on 
magnitude the power flow contributions which herewith is very hoped the fairly results. Then, total revenue (from entities) is calculated with the following formulation.

$T R=\sum_{\text {line }} C_{G i} P_{G i}+\sum_{\text {line }} C_{T i} P_{T i}$

Where $T R$ is revenue total, $C_{G i}$ and $C_{T i}$ are cost allocations for generators and bilateral contracts, and $P_{G i}$ and $P_{T i}$ are power from generators and bilateral contracts, respectively,. After obtaining the values of TEC and $T R$, then the deviation can be determined easily by:

$$
\Delta=\frac{T R-T E C}{T E C} 100 \%
$$

Where $\Delta$ is deviation in percent.

From Table 9 above it can be stated that methods of publication (row 3 until row 6 ) have deviation about 12.5 $\%$, which is greater than TEC, or the transmission provider gets benefit. In the reality, TEC has been covered by revenues of generators. Whereas revenues of bilateral contract transactions are benefit for trensmission provider. It is different to the proposed method where the deviation is always zero. This is caused by the power flow contributions are calculated integratedly on the proposed method,

Another difference occurs on determining cost allocation for bilateral contract transaction. The methods of publication are based on wheeling transaction, where the power generated by wheeling transaction always goes into grid, and the power contribution on a certain line from generator of wheeling transaction will be recieved by the load of that wheeling transaction. This is caused by asumption that all power flows of wheeling transaction are always to going toward its load. So, the cost allocation for bilateral contract transaction will be greater. For the proposed method, the power flow contributions are calculated integratedly. Power generated by a bilateral contract transaction at a certain bus is only one part of the power going to that grid when the bus has loads. This yields cost allocation for bilateral contract transaction smaller.

Table 10 consists of the revenues from generators $(\mathrm{G} 1+\mathrm{G} 2)$ and bilateral contract transactions (T1+T2) in the percentage. Generally, for the published methods give almost the same compositions between G1+G2 and $\mathrm{T} 1+\mathrm{T} 2$. While the proposed method gives composition lower. From table 10 shows the published methods produce revenue compositions about $99.2 \%$ for G1+G2 and $12.4 \%$ for $\mathrm{T} 1+\mathrm{T} 2$, or TR equal to $111.6 \%$. In this case the revenues are $11.6 \%$ greater. The over revenues can be said as the profit of the transmission provider. For example: LUFs has revenues from G1+G2: $99.2 \%$ and from T1+T2: $12.8 \%$, or TR is $111.9 \%$. In this case the profit of transmission provider is $11.9 \%$. The profit is not suitable with spirits of this paper, i.e. transmission provider is a non-profit board. The spirit can be shown by the proposed method. The method produces revenues for G1+G2: $92.5 \%$ and $\mathrm{T} 1+\mathrm{T} 2: 7.5 \%$, or TR is equal to $100 \%$. Where the bilateral contracts paid a very small portion because the power is only $6.2 \%$ of total power system.
Table 9 and 10 show the differences between results of the proposed method with the methods of publication. These are due to the different approaches that yield power flow contributions from generators and bilateral contracts on each line are different, both among the methods of publication themselves (Tables 2, 3, 4 and 5) or with the proposed method (Table 8). In general, the methods of publication do not involve the bilateral contract (or called with an unintegrated system), which is shown by Figure 3 with the base data in Table 1. Then bilateral contracts is calculated separately. While on the proposed method, bilateral contracts incorporated into the system to form an integrated system is shown by fig. 4 with the base data in Tables 6 and 7.

Each method produces total MW different in each line shown by Table 11. If the total MW were compared with actual MW flow (in Table 7), for methods of publication are not the same, while the proposed method is the same. It's that show a fundamental difference between the methods of publication with the proposed method, as described in section I:

- The proposed method uses a base case in accordance with the fact, including bilateral contracts, while the methods of publication use a base case without bilateral contracts.

- The methods of publication use the assumptions or approachs, while the proposed method does not.

\section{CONCLUSION}

A method for determining cost allocation of transmission usage is proposed in this paper. Mathematically, the metodology of the method has been illustrated clearly without assumptions and approximations. The proposed method uses the decomposition method that has been studied experimentally by [4]. In this method, bilateral contract transactions are bundled up integratedly into the system (as shown in Figure 3) so that it forms an integrated system (shown by Figure 4), and then it produces an integated basic bases (as shown in Table 6 and 7) from load flow solusion. The power flow contributions of each generator in every line are determined based on the integated basic base. From numerical example (for the 5bus test system above) shows that the proposed method can be applied successfully as is shown in Table 8. Table 9 shows that the proposed method works as is expected, i.e. the revenues are equal to the total embedded cost (non-profit) and the revenues from bilateral contract transaction $7.5 \%$ with the portion of its power is $6.2 \%$ of total power 160.259 MW. There are different results between both the proposed method and the published methods as shown ini Table 10 and 11 . Table 10 shows that the published methods produce revenues about 11.6 $\%$ greater, where the proposed method it is the same. Table 11 shows the power flow contributions of generators on each line are greater than the actual power flows for the published methods, while for the propose method it is same. 


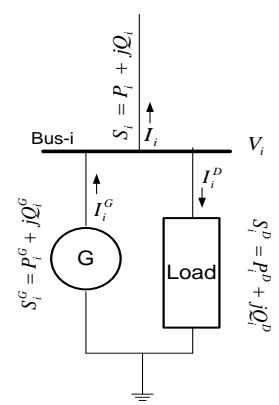

Figure 1. Bus equivalent circuit

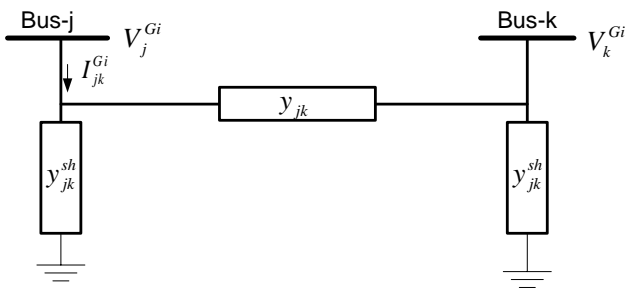

Figure 2. Phi equivalent circuit of line $\mathrm{j}-\mathrm{k}$

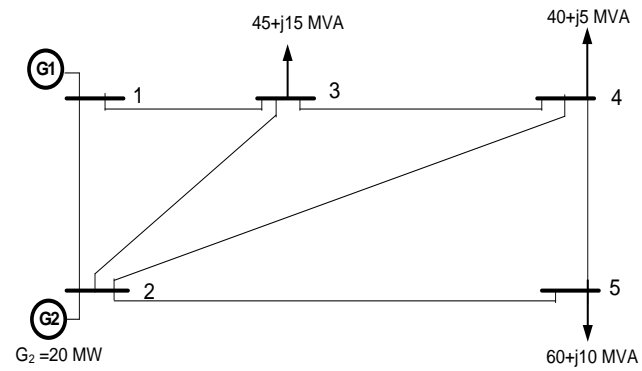

Figure 3. The 5-bus test system

TABLE 1.

TRANSMission Data and THE Base CASE Flows

\begin{tabular}{cccccc}
\hline Line & $\mathrm{R}(\mathrm{pu})$ & $\mathrm{X}(\mathrm{pu})$ & Cost $\left(10^{6} \$\right)$ & Flows $(\mathrm{MW})$ & Flows $(\mathrm{MVA})$ \\
\hline $1-2$ & 0.02 & 0.06 & 0.1863 & 89.51 & 118.27 \\
$1-3$ & 0.08 & 0.24 & 0.8250 & 41.76 & 47.45 \\
$2-3$ & 0.06 & 0.18 & 0.5499 & 24.51 & 24.71 \\
$2-4$ & 0.06 & 0.18 & 0.5499 & 27.75 & 28.05 \\
$2-5$ & 0.04 & 0.12 & 0.2809 & 54.76 & 55.96 \\
$3-4$ & 0.01 & 0.03 & 0.0978 & 19.30 & 19.88 \\
$4-5$ & 0.08 & 0.24 & 0.8250 & 6.54 & 6.94 \\
\hline
\end{tabular}

TABLE 3.

TRANSMISSION USAGES AND CHARGES $\left(\mathrm{G}_{2}\right)$

\begin{tabular}{ccccc}
\hline Line \# & GSDFs (MW) & LUFs (MW) & Bialak (MW) & Kirchen (MW) \\
\hline $1-2$ & -2.7939 & -2.7488 & 0 & 0 \\
$1-3$ & 2.7939 & 2.8034 & 0 & 0 \\
$2-3$ & 4.4803 & 4.6201 & 4.4763 & 3.2402 \\
$2-4$ & 4.6607 & 4.8344 & 5.0680 & 3.6686 \\
$2-5$ & 7.7359 & 8.1780 & 9.9991 & 7.2380 \\
$3-4$ & 1.0641 & 1.2257 & 1.3226 & 2.5515 \\
$4-5$ & 0.3688 & 0.4424 & 0.8855 & 0.8646 \\
$\begin{array}{c}\text { Cost } \\
\text { \$/MW) }\end{array}$ & 1.9354 & 2.0147 & 2.1151 & 1.7381 \\
\hline
\end{tabular}

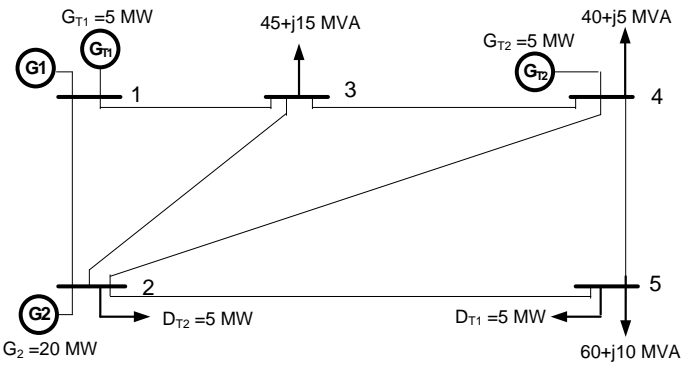

Figure 4. The 5-bus test system with bilateral contracts

TABLE 2.

TRANSMISSION USAGES AND CHARGES $\left(\mathrm{G}_{1}\right)$

\begin{tabular}{ccccc}
\hline Line \# & GSDFs (MW) & LUFs (MW) & Bialak (MW) & $\begin{array}{c}\text { Kirchen } \\
\text { (MW) }\end{array}$ \\
\hline $1-2$ & 92.3039 & 87.0940 & 89.5100 & 89.5100 \\
$1-3$ & 38.9661 & 37.4753 & 41.7600 & 41.7600 \\
$2-3$ & 20.0297 & 20.3981 & 20.0337 & 21.2698 \\
$2-4$ & 23.0893 & 23.6008 & 22.6820 & 24.0815 \\
$2-5$ & 47.0241 & 48.7091 & 44.7509 & 47.5121 \\
$3-4$ & 18.2359 & 18.7771 & 17.9774 & 16.7485 \\
$4-5$ & 6.1712 & 6.4908 & 5.6545 & 5.6754 \\
$\begin{array}{c}\text { Cost } \\
\text { (\$MW) }\end{array}$ & 2.5880 & 2.5756 & 2.5604 & 2.6178 \\
\hline
\end{tabular}

TABLE 4.

TRANSACTION RELATED FLOWS AND CHARGES (T1)

\begin{tabular}{|c|c|c|c|c|}
\hline Line \# & GSDFs (MW) & LUFs (MW) & PFD (MW) & $\begin{array}{c}\text { PFD } \\
\text { (MVA) }\end{array}$ \\
\hline $1-2$ & 3.9286 & 3.7361 & 3.9324 & 3.9325 \\
\hline $1-3$ & 1.0714 & 1.0004 & 1.0725 & 1.0725 \\
\hline $2-3$ & 0.1190 & 0.0732 & 0.1191 & 0.1191 \\
\hline $2-4$ & 0.3175 & 0.2771 & 0.3175 & 0.3175 \\
\hline $2-5$ & 3.4921 & 3,6469 & 3.4927 & 3.4928 \\
\hline $3-4$ & 1.9105 & 1.2067 & 1.1906 & 1.1906 \\
\hline $4-5$ & 1.5079 & 1.5922 & 1.5079 & 1.5079 \\
\hline $\begin{array}{c}\text { Cost } \\
\text { (\$/MW) }\end{array}$ & 4.8961 & 4.9922 & 4.9002 & 4.6230 \\
\hline
\end{tabular}


TABLE 5.

TRANSACTION RELATED FLOWS AND CHARGES (T2)

\begin{tabular}{ccccc}
\hline Line \# & GSDFs (MW) & LUFs (MW) & PFD (MW) PFD (MVA) \\
\hline $1-2$ & 0.8571 & 0.8659 & 0.8657 & 1.8322 \\
$1-3$ & -0.8571 & -0.8831 & -0.8545 & 0.9062 \\
$2-3$ & -1.4286 & -1.4554 & -1.4290 & 1.4356 \\
$2-4$ & -1.8095 & -1.8642 & -1.8097 & 1.8131 \\
$2-5$ & -0.9048 & -0.8853 & -0.9048 & 0.9065 \\
$3-4$ & -2.2857 & -2.4074 & -2.2854 & 2.2917 \\
$4-5$ & 0.9048 & 0.9476 & 0.9058 & 0.9073 \\
Cost & 4.5090 & 4.6581 & 4.5142 & 4.3846 \\
\hline (\$/MW) & & & & \\
\hline
\end{tabular}

TABLE 7.

LINE POWER FLOWS

\begin{tabular}{cccccc}
\hline Bus & Voltage & \multicolumn{2}{c}{ Generator } & \multicolumn{2}{c}{ Load } \\
\cline { 3 - 6 }$\#$ & (pu) & $(\mathrm{MW})$ & MVAR) & $(\mathrm{MW})$ & $(\mathrm{MVAR})$ \\
\hline 1 & 1.050 & 135.37 & 45.2 & 0.0 & 0.0 \\
2 & 1.015 & 20.00 & -2.2 & 5.0 & 0.0 \\
3 & 0.992 & 0.00 & 0.0 & 45.0 & 15.0 \\
4 & 0.990 & 5.00 & 2.9 & 40.0 & 5.0 \\
5 & 0.979 & 0.00 & 0.0 & 65.0 & 10.0 \\
\hline
\end{tabular}

TABLE 9.

Cost AlLocation OF the 5 Methods

\begin{tabular}{|c|c|c|c|c|c|c|}
\hline \multirow{2}{*}{ Method } & \multicolumn{4}{|c|}{ Cost (\$/MW) } & \multirow{2}{*}{$\begin{array}{l}\text { TR } \\
(\$)\end{array}$} & \multirow{2}{*}{$\begin{array}{c}\Delta \\
(\%)\end{array}$} \\
\hline & G1 & G2 & $\mathrm{T} 1$ & $\mathrm{~T} 2$ & & \\
\hline $\begin{array}{l}\text { Proposed } \\
\text { method }\end{array}$ & 2.3915 & 1.9620 & 2.3915 & 3.0856 & 378.4018 & 0.00 \\
\hline GSDFs & 2.5880 & 1.9354 & 4.8962 & 4.5090 & 425.9434 & 12.56 \\
\hline LUFs & 2.5756 & 2.0147 & 4.9922 & 4.6581 & 427.1249 & 12.88 \\
\hline $\begin{array}{c}\text { Bialek/ } \\
\text { PFD- } \\
\text { MW }\end{array}$ & 2.5604 & 2.1151 & 4.9002 & 4.5142 & 425.9552 & 12.57 \\
\hline $\begin{array}{c}\text { Kirchen/ } \\
\text { PFD- } \\
\text { MVA }\end{array}$ & 2.6178 & 1.7381 & 4.623 & 4.3846 & 423.9268 & 12.03 \\
\hline
\end{tabular}

2. $T R$ is total revenue and $\Delta$ is deviation
TABLE 6.

VOLTAGES AND POWERS OF GENERATORS AND LOADS

\begin{tabular}{cccccc}
\hline Bus & Voltage & \multicolumn{2}{c}{ Generator } & \multicolumn{2}{c}{ Load } \\
\cline { 3 - 6 }$\#$ & $(\mathrm{pu})$ & (MW) & MVAR) & (MW) & (MVAR) \\
\hline & & & & & \\
1 & 1.050 & 135.37 & 45.2 & 0.0 & 0.0 \\
2 & 1.015 & 20.00 & -2.2 & 5.0 & 0.0 \\
3 & 0.992 & 0.00 & 0.0 & 45.0 & 15.0 \\
4 & 0.990 & 5.00 & 2.9 & 40.0 & 5.0 \\
5 & 0.979 & 0.00 & 0.0 & 65.0 & 10.0 \\
\hline
\end{tabular}

TABLE 8.

TRANSMISSION USAGES AND CHARGES (ENTITIES)

\begin{tabular}{ccccc}
\hline Line \# & G1 (MW) & G2 (MW) & GT1 (MW) & GT2 (MW) \\
\hline $1-2$ & 92.9660 & -2.7221 & 3.5655 & 0,2071 \\
$1-3$ & 37.4007 & 2.7221 & 1.4344 & $-0,2071$ \\
$2-3$ & 17.5959 & 4.3748 & 0.6748 & $-0,3428$ \\
$2-4$ & 21.6589 & 4,5434 & 0.8307 & -0.6652 \\
$2-5$ & 46.8391 & 7,8745 & 1.7964 & 1,0482 \\
$3-4$ & 18.2242 & 0,9639 & 0.6989 & $-1,9407$ \\
$4-5$ & 7.0539 & 0,5075 & 0.2705 & 1.0247 \\
Cost & 2.3915 & 1.9620 & 2.3915 & 3.0856 \\
\hline (\$MW) & & & & \\
\hline
\end{tabular}

TABLE 10.

REVENUES FROM GENERATORS AND BILATERAL CONTRACT TRANSACTIONS OF THE 5 METHODS

\begin{tabular}{|c|c|c|c|}
\hline \multirow{2}{*}{ Method } & \multicolumn{2}{|c|}{ Revenue (\%) } & \multirow{2}{*}{$T R(\%)$} \\
\hline & $\mathrm{G} 1+\mathrm{G} 2$ & $\mathrm{~T} 1+\mathrm{T} 2$ & \\
\hline $\begin{array}{l}\text { Proposed } \\
\text { method }\end{array}$ & 92,8 & 7,2 & 100,0 \\
\hline GSDFs & 99,2 & 12,4 & 111,6 \\
\hline LUFs & 99,2 & 12,8 & 111,9 \\
\hline $\begin{array}{c}\text { Bialek/ } \\
\text { PFD-MW }\end{array}$ & 99,2 & 12,4 & 111,6 \\
\hline $\begin{array}{c}\text { Kirchen/ } \\
\text { PFD-MVA }\end{array}$ & 99,1 & 11,9 & 111,0 \\
\hline
\end{tabular}

TABLE 11.

TOTAL MW FLOW OF THE METHODS

\begin{tabular}{ccccc}
\hline Line \# & GSDFs (MW) & LUFs (MW) & $\begin{array}{c}\text { Bialek/ Kirchen+ } \\
\text { PFD-MW (MW) }\end{array}$ & Proposed (MW) \\
\hline $1-2$ & 93,4 & 88,1 & 93,4 & 94,0 \\
$1-3$ & 42,8 & 41,3 & 42,8 & 41,4 \\
$2-3$ & 23,1 & 23,6 & 23,1 & 22,3 \\
$2-4$ & 25,9 & 26,6 & 25,9 & 26,4 \\
$2-5$ & 58,3 & 56,9 & 58,2 & 57,6 \\
$3-4$ & 18,9 & 18,8 & 18,2 & 17,9 \\
$4-5$ & 7,7 & 8,1 & 7,2 & 8,9 \\
\hline
\end{tabular}




\section{REFERENCES}

1] Zobian and M.D. Ilic, "Unbundling of transmission and ancillary services-part I: Technical issues and part II: cost based pricing framework", IEEE Trans. on Power system, Vol. 12, No. 2, 1997.

[2] L. Willis, J. Finney, and G. Ramon, "Computing the cost of unbundled services”, IEEE Computer Application in Power, 1997.
[3] P. Jiuping, T. Yonael, R. Saifur, and J. Koda, "Review of UsageBased Transmission Cost Allocation Methods under Open Access", IEEE Transaction on Power Systems, Vol.15, No.4, 2000.

[4] Z. Hemagasantos., "A Proposed method for Determining Power Decomposition”, The $12^{\text {th }}$ Internasional Conference on QiR (Quality in Research), Program Book, Falculty of Engineering Unversitas Indonesia, 2011. 